DOI: $10.46640 /$ imr.9.16.9

UDK 316.772.5:111.32

Prethodno priopćenje Preliminary communication

Primljeno: 14.02.2020.

\title{
Saša Marinović
}

Zagreb, Rudolfa Bićanića 22, Hrvatska

sasa.marinovic@gmail.com

\section{Tijelo kao medij svijeta}

\section{Sažetak}

Pokušat ćemo povezati Merleau-Pontyjevo tumačenje tijela-subjekta s idejom medijalnosti. Tijelo tako postaje medijacijska osnova, kako ljudskog tijela spram ljudskog tijela, tako i ljudskog tijela i svijeta te ljudskog tijela i bitka. Unutar fenomenološkog polja mrežnog su-odnošenja odvija se tako korporalna intersubjektivna igra, klasičnim rječnikom rečeno čovjeka i prirode, u kojojje čovjek konstituiran prirodom kao što je i priroda konstituirana čovjekom i sve to putem tehnike kao onoga što tek treba biti.

Ključne rïječi: mediji, tijelo, tehnika, percepcïa, bitak. 


\section{Uvod}

Da tijelo komunicira s okolinom možda nije ništa novo. Čovjek se kao tijelo, kao um ili kao utjelovljena kognitivnost suodnosi s okolinom. Okolina je ili puki okoliš ili životna sredina, ali ona je nekakva percipirana stvarnost. No, od čega ili koga je percipirana stvarnost percipirana? Od strane svijesti koja je tek transcendentalno nekakvo Ja, Duh i slično, ili od stane svijesti koja to još nije, odnosno od strane nekakvog epifenomenalnog entiteta. Nastavljajući na to, kako je moguće da nešto tako predtjelesno kao što je transcendentalna svijest uopće dođe u mogućnost (a)percipirati tu nekakvu stvarnost ili što god se pod riječi stvarnost podrazumijeva, a da ju se (a)percipira?; kako je moguće da se nešto kao perceptivni aparat uopće nađe u tijelu kao što je ljudsko ili u materiji koja tek treba postati forma čovjeka?; jesmo li sigurni da ono što smo naviknuti percipirati uopće može biti doista percipirano?; može li se prvu i drugu formu percepcije dovoditi i u odnos i ako da, kako?; je li percipirano konstrukt ili struktura?; te naposljetku, je li opravdano razlikovati transcendentalnu od „imanentne“ percepcije i može li ih se tumačiti raznoliko kroz ono što se zove stratigrafsko vrijeme, a da ne zapadnemo u obmanu ili iluziju da percepcija i percipirano postoje kao već gotov subjekt naspram objekta?

Puno je pitanja, ali na svu sreću isto toliko je i odgovora. Ovo će biti jedan od tih odgovora, ali nikako onaj koji pretendira na istinu ili ispravnost. Dapače, da bi se filozofija razvijala kao vječno živa praksa ono što je nužno je greška, možda bolje - ideja/e. No, ne radi se o ideji po sebi, onoj Platonovoj Ideji, već o jednoj drugoj koju nećemo imenovati već radije kreirati ili konstituirati putem, kako Deleuze reče, koncepta, a riječ je dakako, o ravni imanencije.

Prirodna nam se čini činjenica da čovjek postoji kao biološko biće te ga već sama ta fantazma otvara konceptu biološkog horizonta u kojemu se on, kako kaže Vuk-Pavlović ${ }^{121}$, bio-logičkim kontinuitetom otvara spram vremena i u vremenu izvana, dakle vremenu linearnog prijenosa vrijednosti koje tek tu i tamo biva dezavuirano nekakvom aksiološkom inverzijom. Ako nam se dopusti, zvat ćemo ovo zadnje prirodnim vremenom, onim koje protječe za neke mimo nas, a za neke baš upravo zbog nas. Međutim, pored te biološke ravni ili horizonta, postoji i ono koje možemo nazvati tehničkim horizontom ili medijskim vremenom, ono koje se čovjeku otvara posredstvom tehno-medijskog aparata iznutra; ono vrijeme koje McLuhan naziva percepcijom otvorenog polja ${ }^{122}$ gdje čovjek doseže vrhunac predmetne diferencijacije i uranja u predmet sam, postajući i sam predmetom tehnike medija. Za razliku od one prve, ova potonja tvrdnja nam se i ne čini posve prirodnom što možda i jest dobra intuicija, ali budući da se nalazimo u vremenu u kojemu je akademski nedolično ako ne i pompozno imati intuicije, koncepte, fantazme, o tom-potom. To nas vrijeme otvara kaosu kaosa, dakle susrećemo se s barijerom da ostvarimo ono kontingentno konceptualno uranjanje u kaos o kojemu nam Deleuze i Guattari ${ }^{123}$ govore. Oni nas poučavaju o tome kako kaos predstavlja supstrat

121 Pavao Vuk-Pavlović, Filozofija odgoja, Hrvatska sveučilišna naklada, Zagreb 1996.

Pavao Vuk-Pavlović, Ličnost i odgoj, Bogoslovska smotra, vol. 22 (2/1932).

122 Marshall McLuhan, Gutenbergova galaksija, Nolit: Beograd 1973., str. 312.

123 Gilles Deleuze i Felix Guattari, Što je filozofija, Sandor, Zagreb 2017. 
moguće samoizgradnje putem koncepta i ravni imanencije; prvo kao neponovljiva i kontingentna ontogeneza, a drugo kao zaziv onoga što tek treba na osobit način biti. U tom smislu vrijeme medija, tehno-znanstveno vrijeme, kontaminiralo je kaos, te nas je suptilnim fantazmagorijskim metodama izvrglo tehno-kozmosu zbivanja. U takvom kaosu kao tehno-kozmosu sam koncept nije ništa drugo nego tehno-znanstveni prospekt, a ljudi tek samo predmeti. Ovaj rad smjera tome da prikaže jednu od mogućih varijanti objašnjenja tehno-medijskog oblikovanja kvazi-subjekta, da ukaže na njegove zamke i da pokuša ponuditi drugačije mišljenje.

\section{Medijski linearizam Marshala McLuhana}

Smatramo kako je prema učenju Marshala McLuhana važno naglasiti tri bitne točke:

1. sadržaj svakog medija je uvijek neki drugi medij ${ }^{124}$

2. "elektricitet ne centralizira, nego decentralizira“" ${ }^{\text {"125 }}$

3. otvoreno „polje“ kao tip percepcije svijesti ${ }^{126}$

Prva točka kao prva tvrdnja otprije je poznata i prilično je jednostavna. Mediji osim što se razvijaju i postaju efikasniji u medijaliziranju puke informacije, sa svakom novom tehničkom progresijom označavaju i jedan novi društveni trend (što je fetišizacija tehničnosti medija) te postaju jednako tako atraktivni i protoku kapitala, njegovom bržem gibanju i translociranju. McLuhan to jezgrovito formulira: „Sadržaj pisma jest govor, baš kao što je pisana riječ sadržaj tiska, a tisak sadržaj telegrafa“"127. Dakle, ono što se mijenja jesu brzina i razmjer ljudskih odnosa, kao i uzroci tih dviju pojava koje unose promjene u ljudskim odnosima. Ljudi su prostorno postali bliži jedni dugima, a svijet je postao manji. Naglasak je na utjecaju određenog medija na čovjeka, subjekta, sebstvo, jednako kao i na zajednicu, društvo, vrstu, ali to se čini prilično izvanjskim. On nije time beznačajan, ali ne prodire dovoljno duboko. Njegova analiza ostaje na razini elementarnog shvaćanja riječi medium (lat. srednje, posredujuće, sredstvo) gdje se mediji shvaćaju evolutivno od prirodne forme do kulturne tehnike posredovanja informacija ${ }^{128}$. Tijelo je u takvom odnosu stvari da je korisnik medija zarad povećanja efikasnosti jednostavnih tjelesnih performativa. Ono pasivno priliježe uz tehniku medija konzumirajući je tek usputno kao priručnost ili hedonistički kao ne odveć objašnjiv eksces. Tijelo je tek sadržaj nekog drugog kauzaliteta, onog koji za sama tijela još uvijek ne mari jer mu ona nisu primarni predmet razvoja, već samo uzgredno kroz tehničku produkciju. McLuhan naglašava da u trenutku kada bi, kako on kaže, električno doba (doba električne brzine, brzine svjetlosti, elektriciteta) moglo odudarati od linearno evolutivnog objašnjenja medija, ono to ipak ne čini iako je na pravom putu. Električno doba koje McLuhan naziva i točkom istodobnosti koja

124 Marshall McLuhan, Razumijevanje medija, Golden marketing. Zagreb 2008., str. 13.

125 M. McLuhan, Razumijevanje medija, str. 37.

126 M. McLuhan, Gutenbergova galaksija, str. 312.

127 Marshall McLuhan, Razumijevanje medija, str. 13.

128 Žarko Paić u Dražen Katunarić, (ur.), Carstvo medija, Litteris, Zagreb 2012., str.63. 
zamjenjuje slijed ${ }^{129}$, postaje doba strukture i konfiguracije, dakle vrijeme neprestanog oblikovanja. Svijet, subjekt i tijelo ovdje jesu i dalje stabilne kategorije koje koriste kulturni sadržaj na jedan sinkretičan način. Medij je i dalje sredstvo i to sredstvo polisemijske konzumacije kulture; implozija informacija i ekstaza (vizualnih) komunikacija ${ }^{130}$.

Prema tumačenju McLuhana, električni mediji povezuju svijet na jedan hedonističan način, način hedonizma slike, točnije, simbola. To potvrđuje i tvrdnja McLuhana kako „električna brzina miješa pretpovijesne kulture s talogom industrijskih prodavača, nepismenih s polupismenima i poslijepismenima ${ }^{131}$. Povezano - nepovezan pasivni recipijent postaje čovjek u električno doba saturacije informacija u kojemu sadržaj postaje filmska forma kojom je čovjek zabavljan, a nikako informiran ili opismenjavan. Dakle, čovjek je spektakulariziran, pa čak djelomično i subjekt spektakla uništenja - rata, ali samo utoliko što subjektivira svoje tijelo u unaprijed zadanoj medijalnosti. Jedino što se stvarno žrtvuje jest tijelo, duh ne podnosi žrtvu, on je sasvim spokojan. Spokojan je u iluziji da se rat vrši za pravu stvar, jer duh je nazadan, a nazadnim ga čini koncept subjekta koji on nije. S druge strane tijelo je subjekt barem utoliko što je podjarmljeno, što trpi. Ono trpi žrtvu, pamti traumu i tim je ujedno jedini pravi subjekt uništenja kao dekonstrukcije labavog koncepta pred-postavljenosti subjekta.

Druga točka kao druga tvrdnja, ,elektricitet ne centralizira, nego decentralizira“ ${ }^{“ 132}$, vrlo je važna točka McLuhanove pozicije. On ponovno uspostavlja tijelo kao točku komunikacije. Međutim, komunikacija je tu itekako dramaturška ${ }^{133}$, još uvijek ego-centrirana. Električni mediji potiču decentralizaciju koja pobuđuje tijelo na reakciju kao medij sadašnjosti, trenutnosti, neprestane aktualnosti. Ipak, ta istodobnost ${ }^{134}$ nije ona koja ukazuje na prostor-vremensko sažimanje koje bi tvorilo jedan novi način bivanja, jednu novu ontologiju. To je vrijeme u kojemu društveni trendovi bivaju atomizirani, a opet unificirani i homogeni. Günther Anders to opisuje ističući da tehnika „rasijava“, ona tijelo čini ovisnim o „zauzetosti“ ${ }^{135}$ više nego o „zaposlenosti“. Prema Andersu potrebno je da tijelo bude neprestano u pokretu kao izvanjskoj suštini postojanja naspram one unutarnje koja nažalost iščezava. Inverzija suštine i dalje leži u izvanjskom faktoru, onom električnih medija.

Ovdje imamo točku ne-bivanja i točku bivanja. Tijelo kao objektivno prisutno i tijelo kao potencijalno prisutno. Scenarij jedne takve kolizije McLuhan je izrazio riječima: „Jedan od najčeščih uzroka prijeloma u nekom sustavu jest njegovo križanje s kakvim drugim sustavom, kao što je bio slučaj

129 M. McLuhan, Razumijevanje medija, str. 17.

130 Ž. Paić u D. Katunarić, (ur.), Carstvo medija, str. 73.

131 M. McLuhan, Razumijevanje medija, str. 20.

132 M. McLuhan, Ibid., str. 37.

133 Jürgen Habermas, Tumačenja uz pojam komunikacijskog djelovanja, u: Vjeran Katunarić (ur.), Teorija društva u Frankfurtskoj školi, Naprijed, Zagreb 1990., str. 593-619.

134 M. McLuhan, Ibid., str. 17.

135 Gunther Anders, Svijet kao fantom i matrica. Filozofska razmišljanja o radiju i televiziji, Europski glasnik, 10 (10/2005), str. 215. 
s tiskom i tiskarskim strojem na parni pogon, ili pak radijem i filmom (iz čega su nastali zvučni filmovi)“136. Tijelo nije bez posljedica izišlo iz ove ponovne aktualizacije kao temeljnog medija jezika, ono je „reprogramirano“, poboljšano, ono je postalo tijelo 2.o. Biološki sustav je kolizija s električnim, ali i kako McLuhan govori, prijelomnica nekog sustava. Evolucija dolazi na mala vrata, ali GMO i kibernetika na velika. Okoliš kojemu je izvrgnut čovjek u elektroničko doba nije elementarna životna sredina koja je biološkom entitetu potrebna za izmjenu tvari, a ujedno je i estetizirani ambijent (Alpe, Plitvička jezera, Jadransko more, pšenična polja Slavonije...). Prema mišljenju Paula Virilioa okoliš je ono samonametnuto protetično. On smatra kako je urbanizacija vremena (shvaća ju kao čovjekovo sveopće potvrđivanje teletehnike) prije urbanizacija vlastitog tijela koje potpuno zdrav čovjek prepušta prototetičnostima poput tipkovnice, ekrana, kao rukavica ili odijela podataka ${ }^{137}$. Virilio ovdje protezu shvaća kao samo-invalidiziranje, dok je proteza doista nadomjestak čovjekovog nedostatka, naime onog svesvjetskog doživljaja ili sve-svjesnog. Svesvjesno ovdje uzimam kao mogućnost doživljaja onog što McLuhan uzima kao savjest društva; mi cijelo društvo na sebi nosimo kao svoju kožu. Percepcija se mijenja, ona suštinska, aristotelovski rečeno - supstancijalna, percepcijska promjena događa se kao prijelomnica. Svjetlost kao dimenzija potpunog vremena koja i posreduje a naposljetku i uvjetuje percepciju, predstavlja vječno sada koje puca pod težinom praznine, te vraća tijelo u agoniju vremena. Tijelo je u mogućnosti da ponovno postaje vremensko.

U filmu Planeta majmuna (Planet of the Apes, 1968.) fino je prikazana upravo ta bačenost tijela u vrijeme. Astronauti se zatiču na planetu na kojemu sebe smatraju vektorima napretka znanosti i tehnologije, no frapira ih prizor čovjeka koji je vrlo nisko na hijerarhiji živih bića. Naime, ono što su do tada smatrali majmunima, primordijalnim inačicama čovjeka, bića su koja su postala od ljudi ili su ono što su ljudi „nekoć“ bili. Dakle, de-evolucijsko označava kako je pad u vrijeme zapravo ponovno započinjanje čovjeka. Tehnologija kao vječno umjetna mehanika budućnosnog u čovjeku, slomila se pod obzorom kao vlastitom nemogućnošću ograničavanja. Ne-ograničenost jest bez-vremenskost koja „unazađuje“, a zapravo samo ponavlja obrasce „razvoja“, evolucije, napretka, itd. Kip slobode u spomenutom filmu predstavlja svjetlost kao dimenziju koja u jednom povijesnom sagledavanju (ako je takvo kod Virilia moguće), doista traje samo trenutak. Čovjek se ponavlja posredstvom dinamičke procedure tehnogeneze ${ }^{138}$.

Prema tako naizgled apokaliptičnom scenariju društva današnjice, Fromm je pokušao afirmirati koncept nade: 1. potrebno je cjelokupni sistem dovesti u vezu sa „sistemom čovjek“ gdje se identificiraju funkcionalni problemi (gospodarstvo i dobrobit ljudi) te, 2. osvijestiti sve veće ekonomske podjele na bogate i siromašne kao i razvitak civilizacije smrti ${ }^{139}$. Ovo zadnje ogleda se u tendenciji živog čovjeka da ga ne bude, stoga čovjek, kao živo biće, tehnički napredak gotovo

136 M. McLuhan, Ibid., str. 40.

137 Paul Virilio, Brzina oslobađanja, Biblioteka Psefizma,. Karlovac 1999., str. 22.

138 Žarko Paić, Tehnosfera II, Mizantrop, Zagreb 2018., str. 285.

139 Erich Fromm, Revolucija nade, Grafos, Beograd 1978., str. 16. 
pa nesvjesno zaziva kao materijaliziranu smrt. Čovjek nestaje u orgazmičkom bunilu nekrofilne glorifikacije tehnike. No Fromm na umu ima samo tehniku u njenoj uzgrednosti, onu tehniku koja kako veli Heidegger, jest samo priručna (Zeug). Supstancijalna tehnika nikako ne smije biti ukinuta. Ona je elementarna čovjekovom biću, ali njegovo biće neprestano nastaje i to je ono što mnoge buni. Zauzimanje prostora i vremena, već spomenuto kod Andersa, može biti i zauzimanje nekakvog performativa, koliko god on prozaičan bio i stoga procesualna etapa transdukcije Bitka ${ }^{140}$. Suština za Simondona ionako ne dolazi iznutra, već izvana na jedan procesualan način. Tijelo upravo tehničkom prisilom na mehaničke operacije stremi k tome da supstanciju, koja je ona supstancija „unutra“, duša, poprimi tek nakon dovoljno snažne inercije tijela koja će tu mikrodijalektiku moga tijela i moje slike tijela učiniti doista i mojom dušom tijela. „Bit“ tehničkog oslobađa se spontanošću tijela koja zacrtava razvoj „novoga.“

Decentralizacija preko narcističkog efekta nužno dovodi do egzistencijalističkog efekta. Dakle, „društvena svijest“ koja se oslobađa putem niza individualnih „obnažujućih“ oblika nesvjesnog, osobnog i privatnog, dovodi do grižnje savjesti. Na to McLuhan i upućuje u zaključku kada kaže kako „u električnom dobu, cijelo čovječanstvo nosimo na sebi kao svoju kožu. “" ${ }^{141}$ Cijelo čovječanstvo je moje tijelo, ono je moja percepcija i kada govorim o klimatskim promjenama, globalnom zatopljenju, uništavanju Amazone, trovanju oceana..., ne govorim o pojedinačnom iskustvu konkretnog geografskog pojedinca ili zajednice, govorim o društvenom tijelu čovječanstva.

Tu se, McLuhanovim riječima, nazire hibrid dvaju medija, onog tijela i onog tehnike, kao masovnih medija ili interneta. Taj spoj je prema McLuhanu spoj istine i otkrivenja koji rađa novi oblik ${ }^{142}$. Taj sukob, spoj, hibrid, kolizija medija drže nas iznad razine narcističkog dubokog mora, on je „trenutak slobode i oslobađanja od običnog zanosa i otupjelosti koje nameću našim osjetilima“"143. Prostor, ambijent, okoliš, životni prostor nije mistično nešto čime smo okruženi. To nije edenska iščezla geografija, toponimija rajskog života, nego je i čemer, i otužnost, i žrtva, i jad, i bijeda. Prostor je pun „začina života“, stoga McLuhan tako kritički govori o protivnicima reklamiziranog tiska ${ }^{144}$. On je suptilna pojava uključujućeg, isprva samo kao eksploatator hedonističkog potencijala, a nakon zasićenja kao efikasnog medija propulzije medijskog kao tehnoevolucijskog, ali i proto-(a)političkoga potencijala koji se krije u mozaičkom posredovanju i doživljaju vijesti. Taj vrhunac sudjelovanja ali ne i angažiranosti vodi nas prema McLuhanovu pojmu reklame kao „oblika razonode zajednice, koji sam sebe likvidira“"145. Reklama je medij kolektivnog obmanjivanja, tip sudjelovanja koje je bijeg od turobnosti svakodnevice zarad hedonizma unutar virtualnosti. To znači da se slikovno iskustvo reklame, te mozaičnost, kako iskustava, sadržaja, tako i inkluzije, pokazuje kao izvanredna sposobnost utopističkog kolektiviziranja proto-(a)političkog potencijala.

140 Gilbert Simondon u Paić, Tehnosfera II, str. 277-286.

141 M. McLuhan, Ibid., str. 46.

142 M. McLuhan, Ibid., str. 53.

143 M. McLuhan, Ibid., str. 53.

144 M. McLuhan, Ibid., str. 181-192.

145 M. McLuhan, Ibid., str. 206. 
Ako medij doista jest poruka, onda je važna poruka kojoj je ultimativni doseg priopćavanje tijela. Iako je električno doba doba u kojemu je živčani sustav baza produžetka, ciklus medijskosti završava na ljudskom tijelu. Medijska "eshatologija" ili možda cjelokupna tehnička eshatologija, ako ćemo tehničko ovdje uzeti kao medij u mekluanovskom smislu, završava na tijelu. Saturacija, redundantnost, gomila puke informacije prije ili kasnije vraća nas na tijelo. Bolje bi bilo reći, agoniju tijela, kao agoniju povijesnosti.

Treća točka, kao treća tvrdnja, tiče se upravo eshatološkog kod McLuhana. Ona se može iščitavati kao tumačenje koje medije shvaća kao svrhovite bez-svrhovitosti. Možda je to utjecaj tomističke filozofije na McLuhana, a možda je to trenutni doseg vremena koje u njegovoj misli ne može dalje od onog što njegova „logika“ medija nalaže. Naime, mediji su ekstaza neprestane informacije i to doista informacije kao informacije o nečemu što se događa sada, zbiva sada, nečega što jest sada. Sadašnjost i dalje, dakle, postoji kao polje informiranja subjekta. Otvoreno polje je polje zbivanja već gotovog svijeta i subjekta. Ono što čovjek jest, kako smo to već spomenuli, recepcijska je točka, dakle već uspostavljena struktura doživljaja, osjećanja, ako ne i već uspostavljena struktura djelovanja. To potvrđuje i McLuhan kada ističe da se iracionalnim i nelogičnim ponovno otkriva transakcija između čovjekovog “’ja" i "svijeta”, odnosno između subjekta i objekta ${ }^{146}$. Međutim, McLuhan otvara novu temu ali ju nedovoljno eksplicira, pa čak i u knjizi Razumijevanje medija koja dolazi nakon Gutenbergove galaksije kada tvrdi da je pismenost, opet u jednom linearnom smislu shvaćanja, „od prosvjećenog pojedinca načinila zatvoreni sistem i postavila ambis između privida i stvarnosti kome je došao kraj s otkrićem kao što je tok svijesti“i14.

U takvom kontekstu kako smatra Donna Haraway, kibernetika jest transgresija binarnih pozicija poput one temeljne - duh i tijelo. McLuhan transgresiju vidi u koncu linearnosti u vidu abecede ili euklidskog prostora ${ }^{148}$ ali u globalom smislu homeostaza se postiže tek nakon ponovnog iskustva kraha tijela, da bi se ponovno afirmirao u susljednom ciklusu nekog novog tehno-medija. Shvaćajući čovjeka kao neprestanog biološkog ponavljača, ne smije nam se potkrasti pogreška kako biologija znači egzistencijalističku dekadenciju. Biologija je pri samo bitkovnom padu najneposredniji doživljaj prirode od strane čovjeka. Ono što u tom ponavljanju ostaje najveći problem je - što ako se ponavljanje ne uspije ponoviti zbog „tehničkih“ razloga, naime, onih da biološkog supstrata čovjekova ponavljanja ne bude. Taj mogući izostanak Virilio uočava kada ekologiju optužuje za scijentističku enkapsuliranost ${ }^{149}$. Ekologija je u potpunosti indiferentna spram psihološkog vremena. Pasivna optika ${ }^{150}$ doduše jest inertna s aspekta svoje percepcije, stoga ona zaziva aktivnu optiku koja ju predstavlja kao buduće, idealitetno, ali i dramatično i katastrofičko ja, upravo ono juvenilno

146 M. McLuhan, Gutenbergova galaksija, str. 313.

147 M. McLuhan, Ibid., str. 313.

148 Frank Kermode, Između dve galaksije, u: Slobodan Đorđević (ur.), Makluanova galaksija, Biblioteka XX vek, Prosveta, Beograd 1982., str. 131-139.

149 Paul Virilio, Brzina oslobađanja, str. 38-39.

150 Ibid. 
Ja koje nastupa nakon postdramatske fuzije ${ }^{151}$ biološkog i tehnološkog sraza. No, to je zasada stvar ekološke etike ili etike životne sredine.

Na tragu McLuhanove sintagme tok svijesti jest Viriliov princip događajnosti. Viriliovo poimanje događaja ili događajnosti podrazumijeva i dalje subjekt. Upravo tu leži Virilijeva pogreška kada čovjeka smješta u kozmičko vrijeme, vrijeme neprestanog sada zahvaćenog u mreže svjetlosti, odnosno, u škripac „trećeg intervala“. Taj doticaj subjekta - bića s fotonom kao nosiocem ili bolje rečeno fenomenom neprestanog sadašnjeg, anulira ili biće/bitak ili vrijeme, budući da vrijeme, a onda i ono neprestano sada, zahtjeva nekakav koncept subjektivnosti. Ovo potonje destruira svaku opstojnost relativnog te nam ostaje zaključiti da se apsolutno vrijeme ne može shvatiti niti percipirati. Dakle, subjekt iščezava, što nas nagoni na pitanje može li se uopće doseći trenutak kozmičkog vremena ili se uspostavlja novi ciklus novog vremenskog intervala. Uspinjući se prema svjetlosti, po nužnost stvari vosak naših krila se topi i pero naše elacije opada, a čovjek ponovno pada u prostor-vrijeme.

\section{Ambigvitet kao otvorenost tijela spram svijeta}

Jedno od važnijih mjesta u filozofiji Mauricea Merelau-Pontyja jest pojam ambigviteta (ambiguïté). Tim pojmom Merleau-Ponty želi reći kako tijelo postoji na dva načina: fenomenalno i objektivno ${ }^{152}$. Dakle, fenomenalnost tijela pojavljuje se kao istodobno i prisutno i neprisutno. ${ }^{153}$ Ono je prisutno jer već postoji prije same svijesti, ali neprisutno u smislu svog autentičnog bivanja u svijetu. Takvo bivanje je trenutak ,izvornog jedinstva svijesti i svijeta“, tj. bitka koji nismo u mogućnosti konstituirati, ali iz kojeg se sve ostalo konstituira ${ }^{154}$. Konstituiranje je to koje se ostvaruje putem intencionalnosti ili „operativne intencionalnosti“ kako ju imenuje Edmund Husserl. Operativna intencionalnost, za razliku od intencionalnog akta, jest ,prirodno i predpredikativno iskustvo svijeta i našeg života “"155. Svijet i tijelo mogu se doista tumačiti kao odvojeni entiteti ako postoji samo jedno, a da istodobno ono drugo ili „ne postoji“ ili postoji na pasivan ili, u kontekstu medija, radikalno i banalno receptivan način. Mogli bismo ipak zaključiti da ono što se Merleau-Ponty pita jest, ako postoji samo jedan entitet, postoji li uopće bitak. Bitak je, dakle, uvijek dvosmislen (ambiguïté).

Jednostavno rečeno, Merleau-Ponty pokazuje kako tijelo i duša jesu jedno. Tijelo je permanentno prisutna stvarnost, stoga nije puki objekt naspram duše kako to tumači kartezijanski stav. Moje tijelo je moj susret sa svijetom i angažman u njemu. Tijelo i svijet postoje kao već konstituirani, ali tek u srazu tijela i svijeta kao angažmana tijela u tom svijetu započinje projekt tijela-subjekta. Projekt

151 Ibid., str. 85 .

152 Boro Gojković, Dvosmisleni Maurice Merleau-Ponty, Svjetlost, Sarajevo 1979., str. 52.

153 Tijana Okić, Maurice Merleau-Ponty: Problem tijela u fenomenologiji percepcije, Sophos, ZINK, FFSA, Sarajevo, 11 (2011), str. 21.

154 T. Okić, Maurice Merleau-Ponty: Problem tijela u fenomenologiji percepcije, str. 24.

155 Maurice Merleau-Ponty, Fenomenologija percepcije, Veselin Masleša, Sarajevo 1990, str. 17. 
subjektiviranja tijela moguće je ostvariti jedino percepcijom samog svijeta koja je za Merleau-Pontya pred-prisutna stvarnost, ali ona koja je takva jedino u spoju s perspektivom te tako i s tijelom ${ }^{156}$.

Što se dade zaključiti u vrlo kratkom uvodu u Merleau-Pontyjevu filozofiju? Budući da tijelo i svijet jesu modaliteti jednog dvosmislenog bitka, to dvoje je istodobno fundament perspektive koja ako izostaje, uklanja i percepciju svijeta i tijelo. Prostor je već uvijek tu i jedino se u njemu odvijaju percepcija i perspektiva; jedino se u prostoru odvija shvaćanje svijeta i shvaćanje na određen i za onog koji percipira, određujući način. Perceptivno iskustvo je za Merleau-Pontya iskonski susret s bitkom, a bitak je sinonim za biti situiran ${ }^{157}$. Ili, rečeno u kontekstu filozofije medija, „svaki je medij u svojoj povijesno-epohalnoj određenosti tjelesnom strukturom djelovanja istodobno spoznajni aparat i tjelesno situiranje u prostor-vremenu društvenih odnosa i kulturnog poretka značenja“ ${ }^{158}$.

Biti u svijetu pa tako i u svijetu medija nikako ne može biti bez angažmana samo tijela ili samo svijesti. Prema Merleau-Pontyju tijelo, svijest i svijet jesu jedno, ali jedno na perspektivistički način. Taj način nije ništa drugo negoli vlastito oblikovanje u svijetu koji nam je dan jedino kao percepcija, ne kao recepcija. Ovo prvo (percepcija) bilo bi u filozofiji Merleau-Pontyja fenomenalno tijelo, a ovo drugo (recepcija) puko objektivno tijelo, tijelo koje u korporativno-tehničko medijaliziranom svijetu jest uvijek samo objekt. Dakle, u vremenu masovnih medija kao sinonima korporativnog kapitalizma tijelo se želi svesti na ono objektivno, puko biološko vođeno čistim hedonističkim nagonom ili okovano jarmom pukog preživljavanja u ambijentu neprestane proizvodnje. U tom smjeru i ide Husserlova kritika znanosti u djelu Kriza europskih znanosti $i$ transcendentalna fenomenologija koju je Merleau-Ponty pozorno iščitavao. Objektivno tijelo važno je isključivo za znanost, a fenomenalno za nas same, iako su nam na kraju potrebna oba aspekta tijela ali i subjekta koji se njime bavi. Stoga se suvremene znanosti i bave isključivo onim refleksivnim i uvjetujućim aspektom čovjeka, naravno, zbog aplikacije učinkovitih praksi korporativnih proizvoda na same konzumente.

Novomedijski pad tijelo podstiče na dvojaku reakciju - ono je tlačeno sobom i drugim. Tijelo je podvrgnuto jarmu sebstva s ciljem ponovne samoafirmacije, ali i drugima s ciljem instrumentalizacije. Pad tijela je dakle pad slike tijela koja nije produktom tehnike samopostavljanja u interferenciju spram Drugog i drugog, već slike tijela/sebstva kako ju postavlja pragmatika kapitala ilustrirana slikom Kazimira Maljeviča Crni kvadrat na bijeloj podlozi ${ }^{159}$. Medijalnost kao jedini medij današnjice i koji predstavlja perpetuiranje tijela/tehnike kao nosioca isključivo komercijalnog značenja, nužno mora rezultirati u padu tijela kao ponovne uspostave izvornosti života, naime, izvornosti povijesnosti tijela. Tijelo koje postaje virtualitet nije više tijelo povijesnog i kao takvo djelatnog bića. Ono se ne može odrediti kad jednom biva transponirano u virtualno i imaginarno, odnosno, kad i samo postane samoperpetuirajuća fantazma, odnosno fantazma prepetuiranja.

156 Ibid., str. 35.

157 M. Merleau-Ponty, Fenomenologija percepcije, str. 296.

158 Ž. Paić u D. Katunarić (ur.), Carstvo medija, str. 69.

159 Ibid., str. 81 . 
U tjelesnom angažmanu nazire se potreba čovjeka da familijarizira svijet, odnosno učini ga ambijentom primordijalnog shvaćanja prostornosti ${ }^{160}$. Merleau-Pontyjev primordijalni prostor apliciran na objektivni okoliš može se povezati s plemenizmom; to je riječ koju u Razumijevanju medija McLuhan spominje na nekoliko mjesta. Ta poveznica se ogleda u „naviknutosti“ na prostor kao dokaz da moje tijelo nastanjuje prostor na egzistencijalan način. Prostor nije isključivo fizička datost ili geometrijski prostor. Medij je simbol tjelesnog koje želi biti planetarno, tijelo koje želi nadići skučeno plemensko i lokalno da bi u jednoj višoj instanci bilo globalno egzistencijalno tijelo. Informacijsko postaje egzistencijsko i egzistencijalno. Putem tijela su za Merleau-Pontyja moguće mnogostruke dimenzije svijeta percepcije. Tijelo je izvor simbola putem seksualnosti koja je otvorenost bitka tijela.

Otvorenost bitka tijela nužno se mora promatrati kroz medije kao produžetke, odnosno kao fantomske udove putem kojih smo trenutno u stanju osakacenosti. Mediji čine da se „zaborav“ tijela ne odvije nužno kao gotovo i dovršeno zbivanje. „Amnezija“ jest reverzibilni proces ponovne uspostave tijela kao stožera svijeta. Međutim, nešto je uvijek izgubljeno, stoga je reaktualizacija tijela uvijek i rekonfiguracija. Ili je fantomski ud u pitanju ili je bionička ruka, ili premosnica ili sintetički neuron. Vraćanje je uvijek tjelesno, putem tijela ili k njemu, i uvijek uz žrtvu (tijelo pamti). Zaključak ove palingeneze je kako tijelo ili možemo izgubiti i time izgubiti jedan cijeli svijet, ili putem povratnog procesa svijet aktualizirati u tijelu kao iskustvu općeg u pojedinačnom. Stoga mediji nisu ništa drugo, nego - fantomi tijela.

Međutim, fantom nije nešto negativno. Postoji svojevrsna tehnika znaka koja omogućuje da čovjek putem svoje fantomske obrazine postane ono što jest. Osim fantomske konkretnosti, kao što je, npr., tetovaža na ljudskom tijelu ${ }^{161}$, imamo i fantomsku diskretnost u području virtualnog ${ }^{162}$. Emotikon, kako tvrde Argyle i Shields ${ }^{163}$ pozivajući se na Lucea Irigaraya, odražava prisutnost tijela, a konkretno tijelo, tijelo nekog osobno, pronašlo je znak putem kojeg se može ekspresionirati. U jednoj mikrodijalektici između konkretnog tijela i znaka (emotikona), tijelo se na paradoksalan način reafirmira u virtualnom da bi putem tehnike kao „priručnosti“ bitka samoga u njegovom samo-perpetuiranju doseglo temeljnu točku bivanja uopće.

Reafirmacija tijela, ne kao puko biološkog entiteta, već kao vječno prisutne mogućnosti životinjske, čovječje i prirodne neprestane otvorenosti, ono je što u jednom moralnom smislu treba ostati netaknutim. Stoga ekološka etika, primarno kao etika tijela, danas i jest bitna disciplina etike. To više nije ekološka etika kao etika okoliša ili etika životne sredine, već je to etika mogućnosti života, njegove permutacije, pluri-formativnosti, polisemije.

160 B. Gojković, Dvosmisleni Maurice Merleau-Ponty, str. 57.

161 Tetovaže na tijelu danas su raznorodnog karaktera. Raznorodnost simbola tetovaža i njihovog porijekla, prisutni su svi na jednom mjestu, kao na svojevrsnoj oglasnoj ploči, te se tako tijelo javlja kao sinkronicitet istodobno i kao sinkrecitet. Dakle, tijelom komuniciramo mnoštvo bez da koristimo fonemsko komuniciranje. Mi i dalje komuniciramo, a da se ne znamo ili da nismo prisno povezani u razgovoru.

162 Vidi: Katie Argyle. i Rob Shields, Postoji li tijelo u Mreži?, u: Kulture interneta, (ur.) Rob Shields, Jesenski i Turk, Zagreb 2001, str. 85-102.

163 K. Argyle i R. Shields, Postoji li tijelo u Mreži? 
Točka singularnosti koja nužno ide uz pojam reafirmacije tijela, jest prisutnost Mnoštva (kulminacijske točke metamorfoze bitka) na kojoj točki individuacijska modalnost tijela postaje supstancijalna osnova svake individualizacije čovjeka i su-svijeta. Upravo uz ovu točku pristaje Deleuzeov pojam imanencije kao života ${ }^{164}$ koji označava kontingentnost bitka, odnosno mogućnost tijela kao percepcije da ponovno pokrene percepcijske prakse uspostave novog bitka svijeta. Kulminacijska točka metamorfoze predstavlja a-morfnost bitka, te na taj način petrificiranost postojanja koja tim više svoje postojanje izvrgava jačim silama inercije puknuća.

Da zaključimo, dvoznačnost ili ambigvitet nije isključivo percepcijske naravi, ona je i tjelesne naravi, odnosno, ona je tjelesna perceptivnost. Ukoliko tijelo uzmemo kao medij, a dvoznačnost kao temeljnu odrednicu medija, tada medij prethodi izvorniku ${ }^{165}$. Tijelo jest svijet, a nije svijet tijelo, odnosno, dolazimo do Deleuzeovog koncepta postojanje/bivanje kada tijelo jest procesualnost koja čini temelje bitka, a ne bitak koji leži u osnovi procesualnosti tijela.

\section{Zaključak}

Svijet nije ništa drugo nego tehnogenetska budućnost, budućnost koja je kozmički moment „tehničke“ nagonskosti tijela čovjeka kao medija konstrukcije. Svijet jest ono što jest, a slijedeći Heideggera, Ništa jest vječna preokupacija metafizike. Stoga tijelo kao medij svijeta nije ništa drugo nego medij nečeg postajućeg, nečeg što ima biti, određena stvarnost koja to tek ima postati. Vuk-Pavlovićeva biologička nužnost određena kroz njegov pojam odgoja, odražava potrebu za razvojem otvorenosti spram vrijednosti. Međutim vrijednosti nisu neke određenosti, već ono što se putem odgoja mora neprestano otvarati spram svijeta pa tako i otvarati vrijednosti kao postojanosti. Potrebna je nova „vjera u svijet“" kako je to formulirao Deleuze u jednom intervjuu ${ }^{\mathbf{1 6 6}}$.

Tijelo je prvo, zatim je tehnika, potom jezik te naposljetku govor. Tijelo je sjecište trijade tehnika jezik - govor iz kojega izvire smisao svijeta ili svjetova. McLuhan jasno pokazuje metamorfozu tehnike u njenom priručnom potencijalu za čovjeka, međutim, izostaje onaj bitni moment metamorfoze samog bitka. Tehničko je kod McLuhana i dalje odvojena stvarnost od tijela, kao utjelovljene percepcije i nečega što tek treba razviti strukture po-sebnosti. Iako se takav scenarij nazire u onome što smo opisali u točki tri, kao trećoj tvrdnji, McLuhan nije dokučio razinu potpunog rastemeljenja subjekta koji je referentan do početka post-novovjekovlja. Premda McLuhana možemo bez puno oklijevanja uzeti kao filozofa medija, kao filozofa iconic turn-a, čini se da je on ipak filozof medija kao posredovanja, a ne medija ili tehnike kao nove ontologije ili nove metafizike. Medij se još uvijek u McLuhanovim razmatranjima ili razumijevanjima uzima kao objekt naspram tumačenja koje je subjektivno, te se njegovu poziciju razumije kao antropologiju medija ${ }^{167} \mathrm{u}$ kojoj nema mjesta transmedijalnosti medija kao onog čime mediji danas uopće i jesu u centru filozofske pozornosti.

164 Ž. Paić, Tehnosfera II, str. 362.

165 Ž. Paić u D. Katunarić, (ur.) Carstvo medija, str. 60.

166 Ž. Paić, Tehnosfera II, str. 365.

167 Ž. Paić u D. Katunarić (ur.), Carstvo medija, str. 51. 
Začetke upravo takvog jednog rastemljenja nalazimo u misli Merleau-Pontya koji konceptom tijelasubjekta, odnosno tijela kao proto-individualne uronjenosti u unaprijed postojeću perceptivnost, koncepte novovjekovne konstitucije subjekta izvrgava vjetrometini samoprojektirajuce snage inkarnirane perceptivnosti. Tu će započetu misiju rastemljenja Deleuze dovesti do još značajnijeg nivoa, ali ostaje za vidjeti koju značajnu ulogu u takvom razvoju događaja za njega igra tijelo, budući da je tijelo za Merleau-Pontya jedina mogućnost ostvarivanja svijeta, dok je kod Deleuzea ono možda tek manjim dijelom bitan aspekt postojanja previše prepušten diktatu želje, a time i nečeg puko nagonskog. U svakom slučaju, Mereleau-Potyjevo tumačenja tijela kao ambigviteta ostavlja nas sveđ u mogućnosti tumačiti otvorenost $\boldsymbol{J a}$ - projekta spram perspektive. Tijelo kao imanentna prisutnost u materijalnom smislu i tijelo kao imanentna transcendentnost sažeto je $u$ tijelu kao percepciji. U takvoj konstelaciji tijelo je ujedno i tehnika i medij. Tehnika predstavlja potencijalnost/aktualnost onoga što može biti/jest, a medij ono procesualno realizacije. Medij i tehnika neprestana su otvorenost jednog spram drugog. U toj otvorenosti tijelo ne može bez žrtve, tijelo je žrtveni jarac, a tehnika (glas, riječ, tisak, mediji...) otpor, kontrapunkt pukom karnalnom koje, iako iznova pokazuje pad tijela, istom uvijek daje ponovnu razinu dostojanstva.

\section{Literatura:}

Anders, Günther, Svijet kao fantom i matrica. Fỉlozofska razmišljanja o radiju iteleviziji, Europski glasnik, 10 (10/2005), str. 215.

Deleuze, Gilles i Guattari, Felix, Što je filozofija, Sandor, Zagreb 2017.

Fromm, Erich, Revolucija nade, Grafos, Beograd 1978.

Gojković, Boro, Dvosmisleni Maurice Merleau-Ponty, Svjetlost, Sarajevo 1979.

Habermas, Jürgen, Tumačenja uz pojam komunikacijskog djelovanja u: Katunarić, Vjeran (ur.), Teorïja društva u Frankfurtskoj školi, Naprijed, Zagreb 1990., str. 593-619.

Katunarić, Dražen (ur.), Carstvo medija, Litteris, Zagreb 2012.

Kermode, Frank, Između dve galaksije, u: Đorđević, Slobodan (ur.), Makluanova galaksija, Biblioteka XX vek, Prosveta, Beograd 1982., str. 131-139.

McLuhan, Marshall, Gutenbergova galaksija, Nolit, Beograd 1973.

McLuhan, Marshall, Razumijevanje medija, Golden marketing, Zagreb 2008.

Merleau-Ponty, Maurice, Fenomenologïja percepcïje, Veselin Masleša, Sarajevo 1990.

Okić, Tijana, Maurice Merleau-Ponty: Problem tijela u fenomenologiji percepcije, Sophos, ZINK, FFSA, Sarajevo, 11 (2011), str. 48. 
Paić, Žarko, Tehnosfera II, Mizantrop, Zagreb 2018.

Shilds, Rob (ur.), Kulture interneta, Jesenski i Turk, Zagreb 2001.

Virilio, Paul, Brzina oslobađanja, Biblioteka Psefizma, Karlovac 1999.

Vuk-Pavlović, Pavao, Filozofija odgoja, Hrvatska sveučilišna naklada, Zagreb 1996.

\title{
Body as a Media of the World
}

\begin{abstract}
We will try to link Merleau-Ponty's interpretation of the body-subject with the idea of mediation. The body thus becomes the mediating part of the human body towards the human body, human body and the world, and also human body and the Being. Within the phenomenological field of network interaction there is a corporate intersubjective game, usually speaking, between the man and the nature, in which man is constituted by nature as nature is constituted by man, and all this through technique as something that is yet to be.
\end{abstract}

Key words: media, body, technique, perception, being.

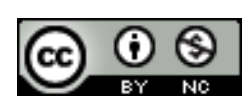

This journal is open access and this work is licensed under a Creative Commons Attribution-NonCommercial 4.0 International License. 